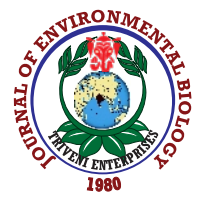

\title{
Statistical optimisation for enhancement of phenol biodegradation by the Antarctic soil bacterium Arthrobacter sp. strain AQ5-15 using response surface methodology
}

\author{
K. Subramaniam ${ }^{1}$, N.A. Shaharuddin ${ }^{1}$, T.A. Tengku-Mazuki ${ }^{1}$, A. Zulkharnain ${ }^{2}$, K.A. Khalil ${ }^{3}$, P. Convey ${ }^{4}$ and S.A. Ahmad ${ }^{1,5 *}$ \\ ${ }^{1}$ Department of Biochemistry, Faculty of Biotechnology and Biomolecular Sciences, Universiti Putra Malaysia, 43400, Serdang, Selangor, Malaysia \\ ${ }^{2}$ Department of Bioscience and Engineering, College of Systems Engineering and Science, Shibaura Institute of Technology, 307 Fukasaku, Minuma- \\ ku, Saitama-337 8570, Japan \\ ${ }^{3}$ Department of Biomolecular Sciences, Faculty of Applied Sciences, Universiti Teknologi MARA, 40450, Shah Alam, Selangor, Malaysia \\ ${ }^{4}$ British Antarctic Survey, NERC, High Cross, Madingley Road, Cambridge CB3 OET, United Kingdom \\ ${ }^{5}$ National Antarctic Research Centre, B303 Level 3, Block B, IPS Building, Universiti Malaya, 50603, Kuala Lumpur, Malaysia
}

*Corresponding Author Email : aqlima@upm.edu.my

\section{Abstract}

Aim: Effective bioremediation requires optimisation of conditions under which the process takes place. In this study, an Antarctic soil bacterium, Arthrobactersp. strain AQ5-15, was evaluated for phenol biodegradation under statistically optimised conditions.

Methodology: The composition of degradation media and the culture conditions for this study were determined according to the experimental requirements obtained from Plackett-Burman factorial design (PB) and Box-Wilson Central Composite Design (CCD), respectively. Phenol degradation was monitored by 4-aminoantipyrine colorimetric assay and bacterial growth was quantified by measuring optical density $\left(\mathrm{OD}_{600 \mathrm{~mm}}\right)$ at $72 \mathrm{hr}$.

Results: A preliminary screening experiment using the Plackett-Burman design indicated that all the factors screened (ammonium sulphate concentration, sodium chloride concentration, $\mathrm{pH}$ and temperature) had significant influence on degradation performance. Response Surface Methodology was then utilised to further optimise the phenol-degrading process using Central Composite Design. The maximum percentage of phenol degradation achieved with CCD was $99.42 \%$, under medium conditions of $0.15 \mathrm{~g} \mathrm{I}^{-1}\left(\mathrm{NH}_{4}\right)_{2} \mathrm{SO}_{4}, 0.13 \mathrm{~g} \mathrm{l}^{-1} \mathrm{NaCl}, \mathrm{pH} 7.25$ and incubation at $15^{\circ} \mathrm{C}$ for $72 \mathrm{hr}$. The strain could degrade phenol when exposed to an initial concentration of up to $1.5 \mathrm{~g}^{-1}$ under these optimised conditions.

Interpretation: The tolerance and degradation characteristics of strain AQ5-15 suggest that it has potential application in bioremediation of polluted sites and in the treatment of relatively cool water bodies contaminated with phenol.

Key words: Arthrobacter sp., Aromatic hydrocarbon, Bioremediation, Indigenous, Psychrotolerant

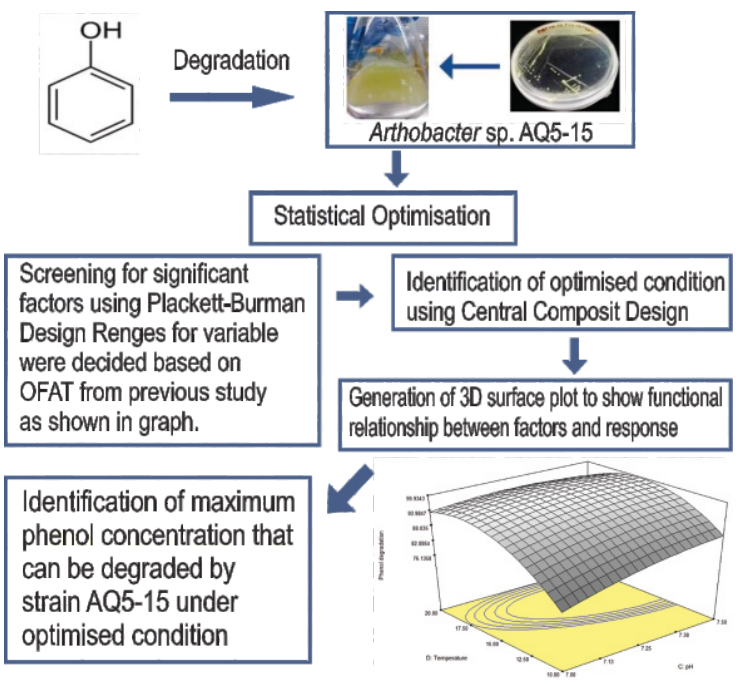

How to cite : Subramaniam, K., N.A. Shaharuddin, T.A. Tengku-Mazuki, A. Zulkharnain, K.A. Khalil, P. Convey and S.A. Ahmad: Statistical optimisation for enhancement of phenol biodegradation by the Antarctic soil bacterium Arthrobactersp. strain AQ5-15 using response surface methodology. J. Environ. Biol., 41, 15601569 (2020). 


\section{Introduction}

Phenol is an aromatic hydrocarbon commonly derived from industrial activities. It has been classified as a high priority toxicant by the United States Environmental Protection Agency (US EPA, 2014) due to its toxicity to living systems and recalcitrant nature. Since Industrial Revolution, there has been a progressive increase in pollution across the globe (Téllez-Pérez et al., 2013). Among pollutants, phenol contamination has become one of the most prevalent in the environment, requiring urgent mitigation actions as it may cause negative impacts on biological systems and also human beings (Zhou et al., 2011; Lee et al., 2017). Anthropogenic pollution is apparent even in the continent that many consider to be the most pristine and isolated, Antarctica. Since the mid-Twentieth Century, the construction and operation of over 50 Antarctic research stations, increasing tourism activities, increased shipping and air transportation and the rapid growth of industrial activities in distant countries of Southern and Northern Hemispheres have resulted in detectable pollution, including phenol, in Antarctica (Bargagli, 2008; Mazuki et al., 2019). Antarctica's ecosystems and biota are highly sensitive to pollution. Furthermore, the continent's chronically cold and harsh climate means that the natural processes involved in remediation of pollution occurs slowly as compared to others places. As a result, pollutants can bioaccumulate in Antarctica's simple ecosystems and food chains (Jara-Carrasco et al., 2017).

Phenol can be removed from the environment by physical and chemical means (Mijangos et al., 2006; Caetano et al., 2009; Mohammadi et al., 2015). However, biological remediation technology has become the preferred approach due to their cost effectiveness, ecofriendly nature, applicability, and usually generates non-toxic end products (Ahmad et al., 2017; SuárezGarcía et al., 2019). The Antarctic Treaty prohibits the importation of non-native organisms into Antarctica, meaning that application of bioremediation approaches in this continent can only be achieved using indigenous microorganisms (Ibrahim et al., 2020). A number of studies have reported the ability of native Antarctic microorganisms, mainly from the genera Arthrobacter and Rhodococcus, to degrade phenol at low temperature (Ahmad et al., 2018; Zakaria et al., 2018). However, identifying such microbes is the stepping stone for the development of bioremediation process. Environmental factors and nutritional parameters such as temperature, $\mathrm{pH}$, salinity, and the presence and type of nitrogen and carbon sources exert important influence on the phenol-degrading capacity and growth rate of microorganisms (Lee et al., 2018; Tengku-Mazuki et al., 2020). Consequently, it is important to optimise these factors to enhance the bioremediation process at laboratory scale, before making an attempt to apply the process in the field environment.

Conventionally, a method such as one-factor-at-time (OFAT) is used for this optimisation process, allowing assessment of optimum value of each factor individually (Vera Candioti et al., 2014). However, this approach is time-consuming and expensive in the case of involvement of multiple variables. In addition, it may not predict the true optimal conditions since interactions between the factors are neglected (Vajic et al., 2015). With advances in statistical analyses and information technology, numerous statistical software packages have been developed as optimisation tools to aid in bioreactor design (Nawawi et al., 2016; Yusuf et al., 2016; Yaacob et al., 2016). One of the well-known software, Design-Expert Version 6, is programmed to calculate the statistical values and probability to define the minimum run of experiments required to recognize significant cause-and-effect relationships between a given number of variables and responses.

This software comprise four categories of Design of Experiment (DoE) which are factorial, response surface, mixture and crossed-process mixture (Alben, 2002). Mathematical and statistical approaches such as Response Surface Methodology (RSM) can be used in optimising multiple factors collectively, avoiding the limitations of single factor optimisation approaches such as OFAT (Zhou et al., 2011). RSM is a sequential procedure that begins with significant factor screening using a two-level factorial design such as Plackett-Burman design (PB) to find the region of optimum, and then modelling and optimising the response with a three-level factorial design such as Box-Behnken Central Composite Design (CCD) (Ibrahim et al., 2015; Karamba et al., 2016). In recent years, many studies have reported the use of RSM to statistically optimise phenol-degrading processes (Sivasubramanian and Namasivayam, 2015; Priyadharshini and Bakthavatsalam, 2016). However, as yet, there has been no application of statistical optimisation for phenol degradation by bacterial strains indigenous to Antarctic continent. The current study addresses statistical approach optimisation using PB design and $C C D$ to enhance the phenol-degrading process by native bacterium, Arthrobactersp. strain AQ5-15.

\section{Materials and Methods}

Inoculum preparation: Arthrobacter sp. strain AQ5-15,a soil bacterium previously isolated from the western part of King George Island, Antarctica (Subramaniam et al., 2019) was used in this experiment. The bacterial strain was retrieved from storage in glycerol at $-80^{\circ} \mathrm{C}$, grown and maintained in nutrient broth (Friendemann Schmidt, Australia) at $10^{\circ} \mathrm{C}$ on an orbital shaker (Protech Model 722, Malaysia) agitated at 150 rpm, in the EcoRemediation Technology Laboratory, Universiti Putra Malaysia. About $10 \%(\mathrm{v} / \mathrm{v})$ of culture was used as standard inoculum throughout this optimisation study.

Optimisation study: Minimal salt medium (MSM) containing $0.5 \mathrm{~g}$ $\mathrm{I}^{-1}$ phenol was inoculated with $10 \%(\mathrm{v} / \mathrm{v})$ of bacterial culture and incubated on the shaking incubator at $150 \mathrm{rpm}$ for $72 \mathrm{hr}$. Uninoculated sterile MSM was used as control for confirming the ability of strain to utilise phenol as a sole carbon source. MSM comprised (per litre) $\mathrm{K}_{2} \mathrm{HPO}_{4}(0.4), \mathrm{KH}_{2} \mathrm{PO}_{4}$ (0.2), $\mathrm{NaCl}(0.1)$, $\mathrm{Mg}_{2} \mathrm{SO}_{4},(0.1),\left(\mathrm{NH}_{4}\right)_{2} \mathrm{SO}_{4}(0.4), \mathrm{MnSO}_{4} \cdot \mathrm{H}_{2} \mathrm{O}(0.01), \mathrm{Fe}_{2}\left(\mathrm{SO}_{4}\right) \cdot \mathrm{H}_{2} \mathrm{O}$ (0.1) and $\mathrm{NaMoO}_{4} \cdot \mathrm{H}_{2} \mathrm{O}$ (0.1). However, the composition of 
degradation media and the culture conditions for this study were determined according to the experimental requirements obtained from Plackett-Burman factorial design (PB) and Box-Wilson Central Composite Design (CCD), respectively. Phenol degradation was monitored at $72 \mathrm{hr}$ using 4-aminoantipyrine colorimetric assay following the of American Public Health Association (APHA, 2005). Based on the method, the $\mathrm{pH}$ of phenol media to be tested was adjusted to $\mathrm{pH} 10$, followed by addition of one percent of 4-aminoantipyrine and potassium ferricyanide from the total media to be tested. The change in colour of the solution and bacterial growth $\left(\mathrm{OD}_{600}\right)$ were quantified using a UV/Visible spectrophotometer (Jenway Model 7305, UK) at $510 \mathrm{~nm}$ and $600 \mathrm{~nm}$, wavelength, respectively.

Experimental design: Researchers focus on statistical approaches like RSM that often produce enormous return-ofinvestment (ROI) at this breakthrough phase (Anderson and Whitcomb, 2004). The core idea of RSM is to use a sequence of designed experiments to achieve one or more optimal responses. The experimental design and statistical analyses were generated using Design-Expert Version 6.0.8 (Stat-Ease Inc. Minneapolis, USA). Each variable $\left(\left(\mathrm{NH}_{4}\right)_{2} \mathrm{SO}_{4}\right.$ concentration, $\mathrm{NaCl}$ concentration, $\mathrm{pH}$ and temperature) was screened using $\mathrm{PB}$, followed by CCD to identify the optimum levels of significant variables obtained from optimisation via OFAT approach from previous study, characterising the response surface in the selected experimental region. Both experiments were run in triplicate with the average of phenol degradation percentage and bacterial growth taken as the responses. The influential variables $(p<0.05)$ screened by PB were selected and optimised using quadratic factorial CCD by combining two factorial points, a sole central point and two axial points $(+2,+1,0,-1,-2)$ (Table 1) leading to a total of 30 runs. The response from the interactions between different factors was specified using a second-order polynomial regression model comprising linear, quadratic and interaction coefficients, as given in eq. 1:

$$
y=\beta_{0}+\sum_{i=1}^{k} \beta_{i} x_{i}+\sum_{i=1}^{k} \beta_{i i} x_{i 2}+\sum_{k<i j j}^{k} \beta_{i j} x_{i} x_{j}
$$

where, $y$ represents the response variable, $x_{i}$ are the independent variables that affect $y, k$ is the number of variables, $\beta_{0}$ indicates the intercept term, $\beta_{i}$ is the $i^{\text {th }}$ linear coefficient, $\beta_{\mathrm{ii}}$ is the $i^{\text {th }}$ quadratic coefficient and $\beta_{i j}$ is the $i^{\text {th }}$ interaction coefficient; $i$ and $j=1,2,3$ where $i \neq j$ are coefficients in the model. In constructing the regression equation for application, the experimental variables were coded based on eq. 2:

$$
x_{i}=\frac{\left(x_{i}-x_{i}\right)}{\Delta x_{i}}
$$

where, $X_{i}$ is the coded value of $I^{\text {th }}$ independent variable, $X_{i}$ is the uncoded value of $i^{\text {th }}$ independent variable, $x_{i}$ is the uncoded value of $i^{\text {th }}$ independent variable at the centre point and $\Delta x_{i}$ is the step change value. The codes are calculated as a function of range of interest of each variable as shown in Table 2 . The significance of model and each coefficient in the equation were examined using Fischer's F-test and Analysis of Variance (ANOVA). The response surface and 3D contour plots of the predicted model were used to evaluate the interaction between significant variables.

\section{Results and Discussion}

As a first step, Plackett Burman factorial design (PB) was used as it is an effective screening method to identify most important variables among multiple variables that have a positive influence on the process being examined (Patil and Jena, 2015; Priyadharshini and Bakthavatsalam, 2016). The significance of four factors, namely $\left(\mathrm{NH}_{4}\right)_{2} \mathrm{SO}_{4}$ concentration $\left(x_{1}\right), \mathrm{NaCl}$ concentration $\left(x_{2}\right), \mathrm{pH}\left(x_{3}\right)$ and temperature $\left(x_{4}\right)$ in phenol degradation by AQ5-15 were analysed with 12 different combinations of experiments as shown in Table 3. The range for all four variables affecting phenol degradation was decided based on the result from OFAT as follows: $0.4-0.6 \mathrm{gl}^{-1}\left(\mathrm{NH}_{4}\right)_{2} \mathrm{SO}_{4}, 0.1$ $0.15 \mathrm{~g} \mathrm{l}^{-1} \mathrm{NaCl}, \mathrm{pH}$ of $7.0-7.5$, temperature at $10^{\circ} \mathrm{C}-20^{\circ} \mathrm{C}$ (Subramaniam et al., 2019). The initial concentration of $0.5 \mathrm{~g} \mathrm{I}^{-1}$ was selected for optimisation based on previous studies which used this concentration for screening for phenol biodegradation (Lee et al., 2018) as higher phenol concentration can be inhibitory to the growth of psychrotolerant bacteria (Li et al., 2010; Sepehr et al., 2019). Table 3 shows both experimental and predicted values for phenol degradation by strain AQ5-15, based on the 12 runs given by PB design. Fischer's F-test showed that the model was significant $(F=558.8259, p=0.0018)($ Table 4$)$.

All four variables exhibited significant effects on phenol degradation and, hence, were employed in the designing of CCD. Das and Chandran (2011) noted that nutrient availability, especially nitrogen source, can act as a limiting factor, and that nutrient concentration might either enhance or inhibit

Table 1: Experimental ranges of independent variables for optimisation using CCD expressed as actual and coded levels

\begin{tabular}{lllllll}
\hline Variable & Symbol & \multicolumn{5}{c}{ Coded level } \\
\cline { 3 - 7 } & & -2 & -1 & 0 & 1 & 2 \\
\hline$\left(\mathrm{NH}_{4}\right)_{2} \mathrm{SO}_{4}$ concentration $\left(\mathrm{g} \mathrm{l}^{-1}\right)$ & $\mathrm{x}_{1}$ & 0.3 & 0.4 & 0.5 & 0.6 & 0.7 \\
$\mathrm{NaCl}$ concentration $\left(\mathrm{g} \mathrm{l}^{-1}\right)$ & $\mathrm{x}_{2}$ & 0.08 & 0.1 & 0.13 & 0.15 & 0.17 \\
$\mathrm{pH}$ & $\mathrm{x}_{3}$ & 6.75 & 7.00 & 7.25 & 7.50 & 7.75 \\
Temperature $\left({ }^{\circ} \mathrm{C}\right)$ & $\mathrm{x}_{4}$ & 5 & 10 & 15 & 20 & 25 \\
\hline
\end{tabular}


Table 2: Relationship between coded and actual value of factors

\begin{tabular}{ll}
\hline Coded value & Actual value \\
\hline-2 & ${ }^{x} \min$ \\
-1 & {$\left[\frac{\left({ }^{x} m a x+{ }^{x} m i n\right)}{2}\right]-\left[\frac{\left({ }^{x} m a x{ }^{-x} \min \right)}{2 \beta}\right]$} \\
0 & {$\left[\frac{\left({ }^{x} m a x+{ }^{x} \min \right)}{2}\right]$} \\
1 & {$\left[\frac{\left({ }^{x} \max { }^{x} \min \right)}{2}\right]-\left[\frac{\left({ }^{x} \max { }^{-x} \min \right)}{2 \beta}\right]-$} \\
2 & ${ }^{x} \max$ \\
\hline
\end{tabular}

$\beta$ is $2^{n / 4} ; n$ is the number of variables where $n=4$

degradation. $\mathrm{NaCl}$ concentration can adversely affect the biological performance of microorganisms dramatically, for instance affecting the suspended solid concentration in effluent and, thus, reducing the efficiency of organic compound removal by inhibiting bacterial metabolism (Chen et al., 2018). pH is also considered highly significant because most microbes are unable to tolerate high or low pH (Shah, 2018). Finally, temperature can affect both the physical state of pollutants as well as directly influence microbial growth rates and metabolic process (Varjani and Upasani, 2017; Subramaniam et al., 2019).

The analysis of variance (ANOVA) of experimental results from the PB design showed that the model was well supported (Table 4). The F-value of 12.637 implied that Lack of Fit was not significant relative to the pure error where there was a $17.46 \%$ chance that a "Lack of Fit F-value" this large could occur due to noise. Insignificancy of lack of fit is good for the model to be fit (Sanusi et al., 2016). ANOVA on the model design displayed a $\mathrm{R}^{2}$ of 0.9996 showing the closeness of data to the fitted regression line. The "Pred R-Squared" of 0.9442 was in reasonable agreement with the "Adj R-Squared" of 0.9978 and the "Adeq Precision" of 60.396 indicated an adequate and satisfactory signal. A low coefficient of variation of value $(0.43 \%)$ showed that the model was precise and highly reliable. The CCD design of
RSM experiments, using all four significant variables from PB, with the experimental and predicted values for phenol degradation are presented in Table 5. A total of 30 sets of experiments were generated by CCD using different sets of values for the variables, including outliers. The maximum percentage of phenol degradation was observed in run 16 $(99.42 \%)$ with medium conditions of $0.15 \mathrm{~g} \mathrm{l}^{-1}\left(\mathrm{NH}_{4}\right)_{2} \mathrm{SO}_{4}, 0.13 \mathrm{gl}^{-1}$ $\mathrm{NaCl}, \mathrm{pH} 7.25$ and incubation temperature of $15^{\circ} \mathrm{C}$. The regression equation coefficients were calculated as shown in Table 6, and the data were fitted to a second-order polynomial equation to be used for predicting optimum combination of conditions. The relationship between phenol degradation and the variables is shown in eq. (3) and (4) in terms of actual and coded factors, respectively. The predicted response is indicated by $Y$ and $x_{1}, X_{2}, X_{3}$ and $x_{4}$ are the coded values of $\left(\mathrm{NH}_{4}\right)_{2} \mathrm{SO}_{4}, \mathrm{NaCl}, \mathrm{pH}$ and temperature, respectively. Positive and negative signs in the regression equation signify either synergistic or antagonistic effects of each variable on the response.

$$
Y=-2027.03896+88.62292 x_{1}+482.02500 x_{2}+
$$

$501.75500 x_{3}+27.02208 x_{4}-88.46875 \times 1^{2}-1883.50000 \times 2^{2}-$ $31.61500 \times 3^{2}-0.34849 \times 4^{2}-2.11950 x_{3} x_{4}$

$$
\mathrm{Y}=+98.37+0.015 \mathrm{x}_{1}+0.28 \mathrm{x}_{2}+2.89 \mathrm{x}_{3}+6.01 \mathrm{x}_{4}-0.88 \mathrm{x} 1^{2}-
$$

$1.18 \times 2^{2}-1.98 \times 3^{2}-8.71 \times 4^{2}-2.65 x_{3} x_{4}$

The ANOVA of experimental results for CCD showed that the experimental data fitted well to the statistical model, with a statistically significant model (Table 6). The "Lack of Fit F-value" of 3.50 indicated $8.86 \%$ chance that a "Lack of Fit F-value" this large could occur due to noise and insignificant lack of fit is needed for a model to fit. The value of Prob $>F<0.0001$ illustrated that the two linear terms $\left(x_{3}, x_{4}\right)$, all four quadratic terms $\left(x 1^{2}, x 2^{2}\right.$, $\left.x 3^{2}, x 4^{2}\right)$ and one interaction term $\left(x_{3} x_{4}\right)$ of the model were significant, and the model specified that the two most influential variables were $\mathrm{pH}\left(\mathrm{x}_{3}\right)$ and temperature $\left(\mathrm{x}_{4}\right)$. Based on the regression analysis of the model, the coefficient determination, $R^{2}$ was found to be 0.9825 presenting a high correlation between the

Table 3: Experimental design given by PB and results on phenol degradation by strain AQ5-15 using different parameters

\begin{tabular}{lllllll}
\hline Run & $\mathbf{x}_{\mathbf{1}}$ & $\mathbf{x}_{\mathbf{2}}$ & $\mathbf{x}_{\mathbf{3}}$ & $\mathbf{x}_{\mathbf{4}}$ & Experimental value (\%) & Predicted value (\%) \\
\hline 1 & 0.60 & 0.10 & 7.50 & 20.00 & 92.25 & 92.36 \\
2 & 0.40 & 0.15 & 7.50 & 20.00 & 92.00 & 91.77 \\
3 & 0.40 & 0.10 & 7.00 & 10.00 & 76.30 & 76.07 \\
4 & 0.40 & 0.15 & 7.00 & 10.00 & 71.89 & 72.00 \\
5 & 0.60 & 0.10 & 7.50 & 10.00 & 82.76 & 89.53 \\
6 & 0.40 & 0.10 & 7.00 & 20.00 & 89.87 & 85.79 \\
7 & 0.40 & 0.15 & 7.50 & 10.00 & 85.68 & 88.79 \\
8 & 0.40 & 0.10 & 7.50 & 20.00 & 88.68 & 72.26 \\
9 & 0.60 & 0.10 & 7.00 & 10.00 & 72.15 & 91.79 \\
10 & 0.60 & 0.15 & 7.00 & 20.00 & 91.95 & 91.34 \\
11 & 0.60 & 0.15 & 7.50 & 10.00 & 91.23 & 91.79 \\
\hline
\end{tabular}


Table 4: ANOVA for phenol degradation by strain AQ5-15 using PB design

\begin{tabular}{|c|c|c|c|c|c|}
\hline Source & Sum of Squares & DF & Mean Square & F-Value & Prob $>F$ \\
\hline Model & 685.8599 & 9 & 76.20665 & 558.8259 & $0.0018^{* *}$ \\
\hline $\mathrm{x} 1$ & 16.95402 & 1 & 16.95402 & 124.3243 & $0.0079^{* *}$ \\
\hline$x 2$ & 10.44493 & 1 & 10.44493 & 76.59303 & $0.0128^{*}$ \\
\hline$x 3$ & 140.8485 & 1 & 140.8485 & 1032.847 & $0.0010^{* * *}$ \\
\hline$x 4$ & 261.7335 & 1 & 261.7335 & 1919.3 & $0.0005^{* * *}$ \\
\hline$x 1 \times 2$ & 15.79722 & 1 & 15.79722 & 115.8415 & $0.0085^{\star *}$ \\
\hline$x 1 \times 3$ & 6.732016 & 1 & 6.732016 & 49.36609 & $0.0197^{*}$ \\
\hline$x 1 \times 4$ & 6.892879 & 1 & 6.892879 & 50.54571 & $0.0192^{*}$ \\
\hline$\times 2 \times 3$ & 23.05602 & 1 & 23.05602 & 169.0706 & $0.0059^{* *}$ \\
\hline$x 3 \times 4$ & 29.21922 & 1 & 29.21922 & 214.2655 & $0.0046^{* *}$ \\
\hline Residual & 0.272738 & 2 & 0.136369 & & \\
\hline Lack of Fit & 0.252738 & 1 & 0.252738 & 12.63692 & 0.1746 \\
\hline Pure Error & 0.02 & 1 & 0.02 & & \\
\hline Cor Total & 686.1326 & 11 & & & \\
\hline Std. Dev & 0.37 & & & $\mathrm{R}^{2}$ & 0.9996 \\
\hline Mean & 85.54 & & & Adj $R^{2}$ & 0.9978 \\
\hline C.V. & 0.43 & & & Pred $\mathrm{R}^{2}$ & 0.9442 \\
\hline PRESS & 38.30 & & & Adeq precision & 60.396 \\
\hline
\end{tabular}

*: $p<0.05 ;{ }^{* *}: p<0.01 ;{ }^{* * *}: p<0.001$

Table 5: Experimental design given by $C C D$ and results on phenol degradation by strain $A Q 5-15$ using significant parameters from $P B$

\begin{tabular}{|c|c|c|c|c|c|c|}
\hline Run & $x_{1}$ & $\mathbf{x}_{2}$ & $\mathbf{x}_{3}$ & $\mathbf{x}_{4}$ & Experimental value (\%) & Predicted value (\%) \\
\hline 1 & 0.50 & 0.08 & 7.25 & 15.00 & 94.14 & 93.10 \\
\hline 2 & 0.70 & 0.13 & 7.25 & 15.00 & 94.48 & 94.86 \\
\hline 3 & 0.40 & 0.15 & 7.50 & 10.00 & 85.68 & 85.35 \\
\hline 4 & 0.50 & 0.17 & 7.25 & 15.00 & 94.98 & 94.21 \\
\hline 5 & 0.60 & 0.15 & 7.00 & 10.00 & 75.28 & 74.90 \\
\hline 6 & 0.40 & 0.10 & 7.00 & 20.00 & 90.87 & 91.62 \\
\hline 7 & 0.50 & 0.13 & 6.75 & 15.00 & 86.45 & 84.69 \\
\hline 8 & 0.30 & 0.13 & 7.25 & 15.00 & 96.98 & 94.80 \\
\hline 9 & 0.40 & 0.10 & 7.50 & 10.00 & 85.39 & 85.90 \\
\hline 10 & 0.40 & 0.15 & 7.00 & 20.00 & 87.60 & 90.12 \\
\hline 11 & 0.50 & 0.13 & 7.25 & 5.00 & 50.25 & 51.51 \\
\hline 12 & 0.50 & 0.13 & 7.25 & 15.00 & 98.36 & 98.37 \\
\hline 13 & 0.60 & 0.10 & 7.50 & 20.00 & 92.37 & 91.53 \\
\hline 14 & 0.50 & 0.13 & 7.25 & 15.00 & 96.23 & 98.37 \\
\hline 15 & 0.60 & 0.15 & 7.50 & 10.00 & 87.96 & 85.97 \\
\hline 16 & 0.50 & 0.13 & 7.25 & 15.00 & 99.42 & 98.37 \\
\hline 17 & 0.40 & 0.15 & 7.00 & 10.00 & 72.07 & 74.28 \\
\hline 18 & 0.60 & 0.15 & 7.50 & 20.00 & 91.23 & 93.20 \\
\hline 19 & 0.40 & 0.15 & 7.50 & 20.00 & 92.04 & 90.60 \\
\hline 20 & 0.60 & 0.10 & 7.50 & 10.00 & 82.76 & 83.36 \\
\hline 21 & 0.40 & 0.10 & 7.00 & 10.00 & 76.29 & 74.83 \\
\hline 22 & 0.50 & 0.13 & 7.25 & 25.00 & 78.59 & 75.53 \\
\hline 23 & 0.50 & 0.13 & 7.75 & 15.00 & 96.28 & 96.23 \\
\hline 24 & 0.50 & 0.13 & 7.25 & 15.00 & 98.45 & 98.37 \\
\hline 25 & 0.40 & 0.10 & 7.50 & 20.00 & 88.68 & 92.10 \\
\hline 26 & 0.60 & 0.10 & 7.00 & 10.00 & 72.15 & 72.29 \\
\hline 27 & 0.50 & 0.13 & 7.25 & 15.00 & 98.32 & 98.37 \\
\hline 28 & 0.60 & 0.10 & 7.00 & 20.00 & 90.29 & 91.06 \\
\hline 29 & 0.50 & 0.13 & 7.25 & 15.00 & 99.41 & 98.37 \\
\hline 30 & 0.60 & 0.15 & 7.00 & 20.00 & 91.95 & 92.73 \\
\hline
\end{tabular}


Table 6: ANOVAfor phenol degradation by strain AQ5-15 using CCD

\begin{tabular}{|c|c|c|c|c|c|}
\hline Source & Sum of squares & DF & Mean square & F-Value & Prob $>F$ \\
\hline Model & 3282.67 & 9 & 364.74 & 90.47 & $<0.0001^{* * *}$ \\
\hline$x_{1}$ & 5.704E-003 & 1 & 5.704E-003 & $1.415 \mathrm{E}-003$ & 0.9704 \\
\hline$x_{2}$ & 1.86 & 1 & 1.86 & 0.46 & 0.5042 \\
\hline$x_{3}$ & 199.93 & 1 & 199.93 & 49.59 & $<0.0001^{* \star *}$ \\
\hline$x_{4}$ & 865.56 & 1 & 865.56 & 214.70 & $<0.0001^{* * *}$ \\
\hline$x 1^{2}$ & 21.47 & 1 & 21.47 & 5.32 & $0.0318^{*}$ \\
\hline$x 2^{2}$ & 38.01 & 1 & 38.01 & 9.43 & $0.0060^{* *}$ \\
\hline$x 3^{2}$ & 107.09 & 1 & 107.09 & 26.56 & $<0.0001^{\star * *}$ \\
\hline$x 4_{2}$ & 2081.89 & 1 & 2081.89 & 516.40 & $<0.0001^{\star * *}$ \\
\hline $\mathrm{x}_{3} \mathrm{x}_{4}$ & 112.31 & 1 & 112.31 & 27.86 & $<0.0001^{* * *}$ \\
\hline Residual & 80.63 & 20 & 4.03 & & \\
\hline Lack of Fit & 73.86 & 15 & 4.92 & 3.64 & 0.0803 \\
\hline Pure Error & 6.77 & 5 & 1.35 & & \\
\hline Cor Total & 3363.30 & 29 & & & \\
\hline Std. Dev & 2.01 & & & $\mathrm{R}^{2}$ & 0.9760 \\
\hline Mean & 88.17 & & & Adj $R^{2}$ & 0.9652 \\
\hline C.V. & 2.28 & & & Pred $R^{2}$ & 0.9320 \\
\hline PRESS & 228.76 & & & Adeq precision & 40.423 \\
\hline
\end{tabular}

${ }^{*}: p<0.05 ;{ }^{* *}: p<0.01 ;{ }^{* * *}: p<0.001$

Table 7: Model validation for phenol degradation by strain AQ5-15

\begin{tabular}{lll}
\hline Factors & Predicted value & Experimental value \\
\hline$\left[\left(\mathrm{NH}_{4}\right)_{2} \mathrm{SO}_{4}\right]\left(\mathrm{g} \mathrm{l}^{-1}\right)$ & 0.50 & 0.50 \\
{$[\mathrm{NaCl}]\left(\mathrm{g} \mathrm{l}^{-1}\right)$} & 0.10 & 0.10 \\
$\mathrm{pH}$ & 7.04 & 7.04 \\
Temperature $\left({ }^{\circ} \mathrm{C}\right)$ & 15.76 & 16.00 \\
Phenol degradation $(\%)$ & 95.33 & 96.42 \\
\hline
\end{tabular}

experimental design data. The "Pred R-Squared" of 0.9209 is in reasonable agreement with the "Adj R-Squared" of 0.9682. "Adeq Precision" of 35.732 indicated an adequate signal as it measures that the signal to noise ratio and a ratio greater than 4 is desirable. These results specify that these significant factors can act as limiting factors and minute variations in their value can affect the degradation rate of phenol.

Similarity between the predicted and actual analyses of the effects of variables on phenol degradation is shown in Fig. 1. The plot displays a close correlation between predicted and actual data as data points were accumulated closer to the line that bisects the plot at an angle of $45^{\circ}$. Based on Table 6 and Fig. 1, it can be deduced that the predicted values attained from the quadratic model were in good agreement with the experimental values (Sanusi et al., 2016). This RSM tool comprised features for point prediction and interpret graphically through $3 \mathrm{D}$ response surface curve that could be handy in predicting the optimum value of significant factor interaction for maximum phenol degradation efficiency. Fig. 2 illustrates the 3D plot for optimum phenol degradation with combination of significant variables $\left(x_{3}\right.$ and $\left.x_{4}\right)$.
The slightly elliptical 3D plot shows interaction between the two most significant factors namely $\mathrm{pH}$ and temperature. The curved response surface specified that there are well-defined optimal variables because flat surface near the optimum means the optimised values may not differ largely from single variable conditions (Ibrahim et al., 2015). The model predicted that maximum phenol degradation will be achieved between $\mathrm{pH} 7.13$ 7.5 and temperature range of $15^{\circ} \mathrm{C}-17.5^{\circ} \mathrm{C}$. Here it can be observed that the efficiency of phenol degradation having a negative effect at low temperature and acidic condition as well as at high temperature and alkaline condition. The temperature effect was more notable at $\mathrm{pH} 7$ and 7.5 , thus maximum phenol degradation can be achieved at neutral or near neutral condition with increased temperature.

Temperature is normally considered as one of the most influential factors, particularly in polar region as degradation must obey the Arrhenius law. According to the Arrhenius relationship, the degradation of a pollutant is highly dependent on temperature in where an increase or decrease in temperature can affect the rate of degradation (Arrhenius, 1889; Kulkarni et al., 2017). This 


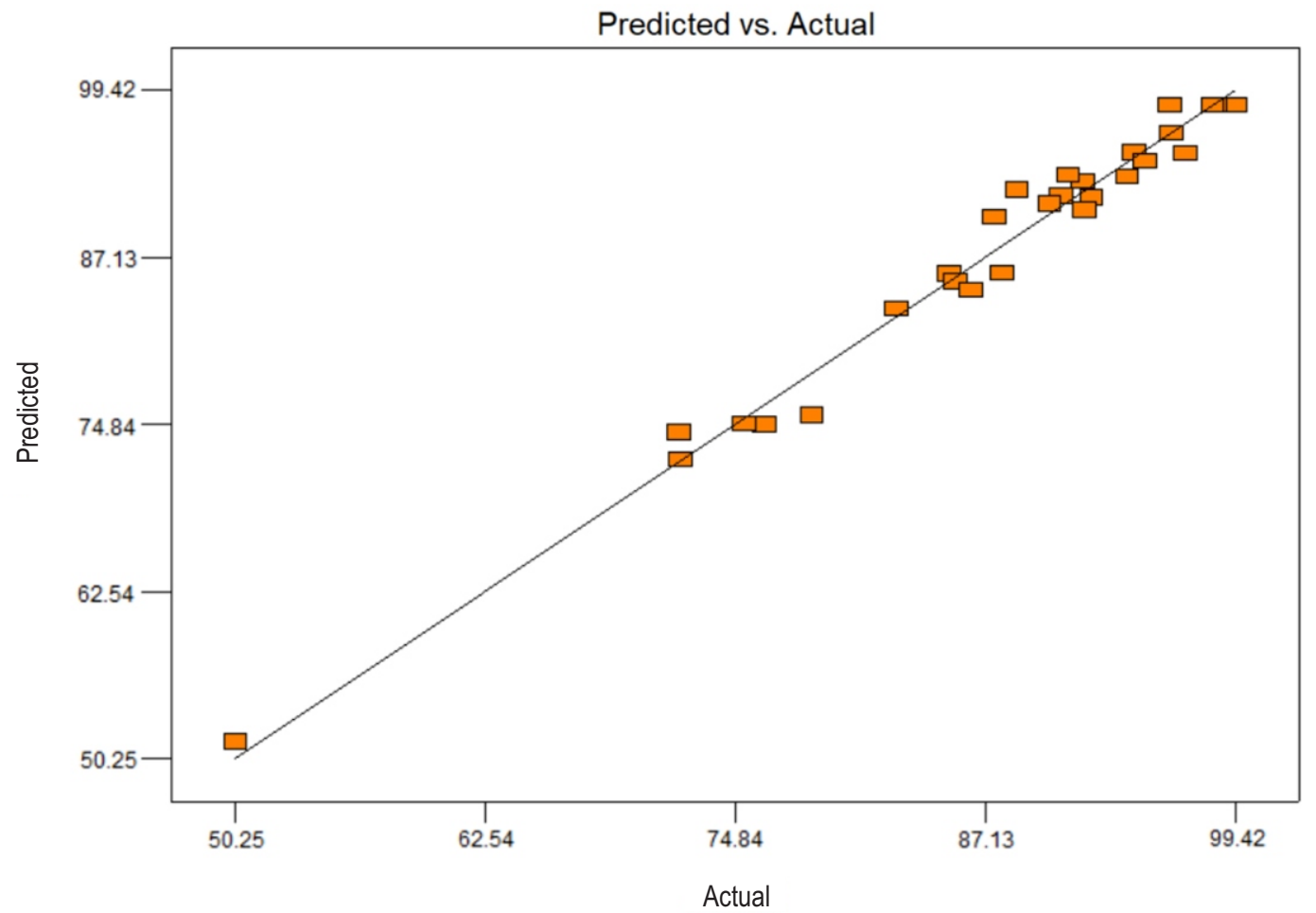

Fig. 1: Similarity plot between predicted and actual values for phenol biodegradation by strain AQ5-15.

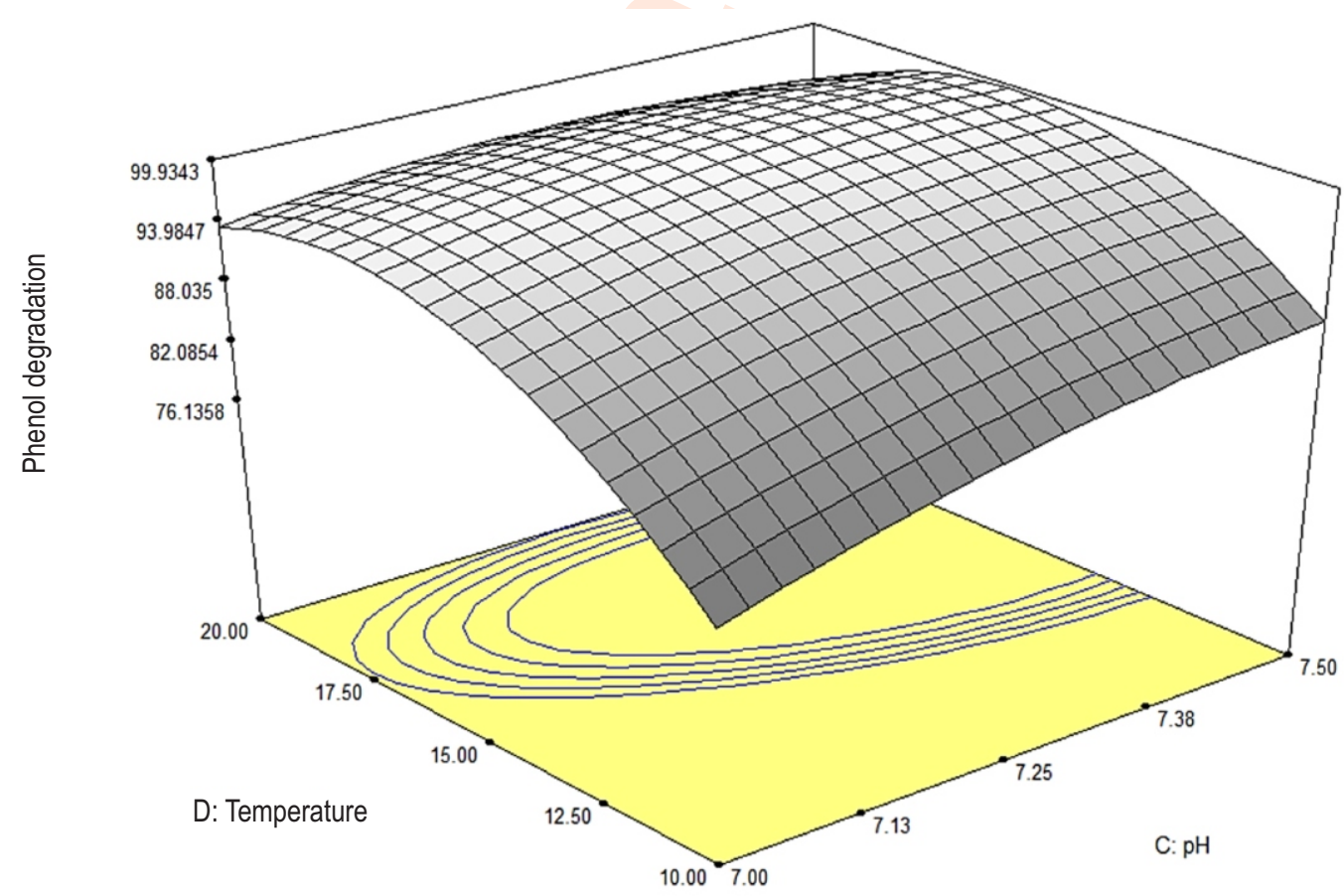

Fig. 2: 3D response surface plot showing interaction effect between significant variables, $\mathrm{pH}$ and temperature during phenol biodegradation by the strain AQ5-15. 

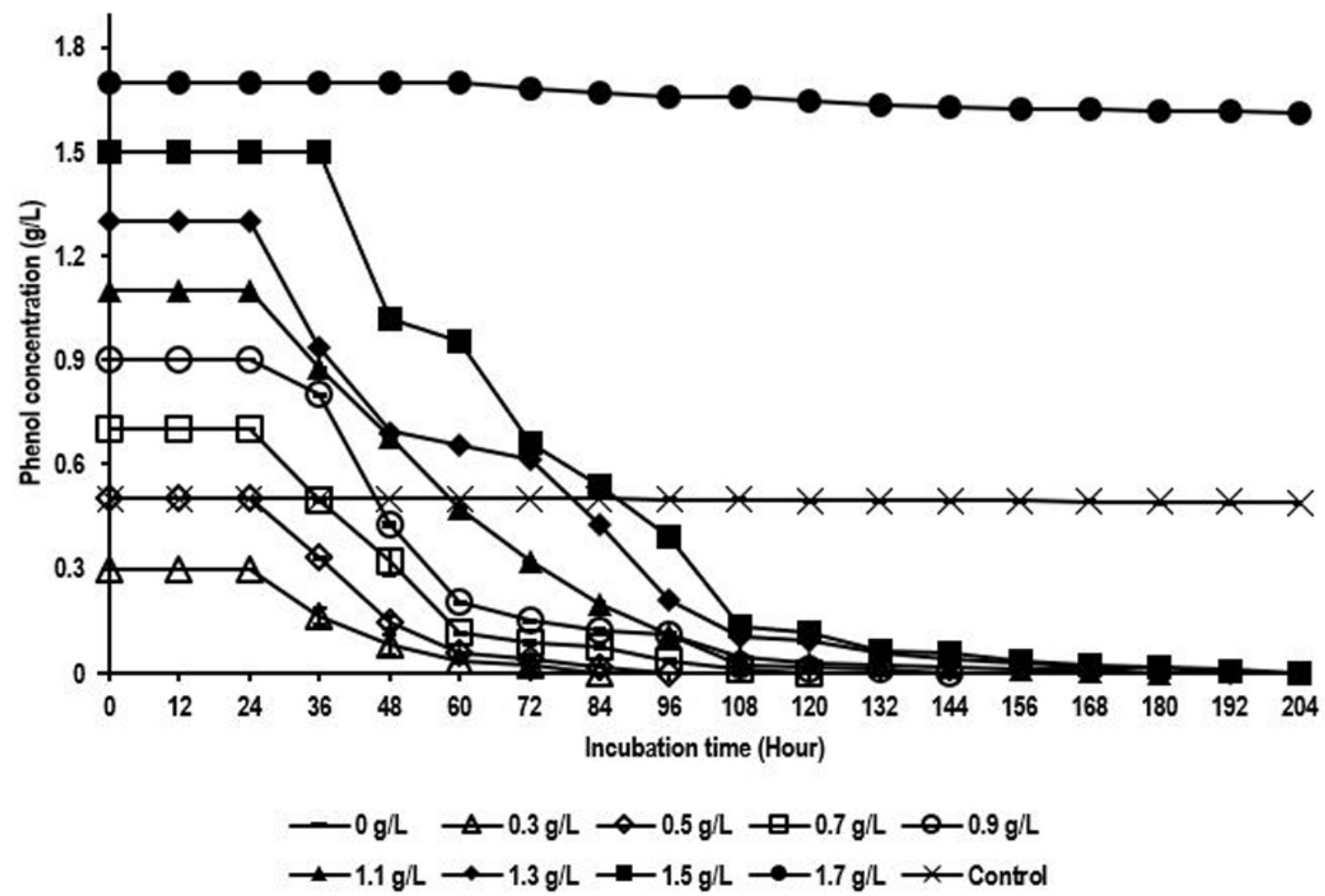

Fig. 3: Biodegradation of different initial concentrations of phenol by strain AQ5-15 under optimised conditions. Error bars represent mean \pm standard deviation $(n=3)$.

optimum temperature for phenol degradation by strain AQ5-15 supports the potential use of this strain for phenol degradation in soils in cold regions. Similar to this strain, most hydrocarbondegrading Antarctic bacteria have been reported to be facultatively psychrotolerant with optimum temperature for biodegradation activity ranging between $10-20^{\circ} \mathrm{C}$ (GranScheuch et al., 2017; Roslee et al., 2019).

However, highly seasonal polar regions like Antarctica generally have annual mean air temperature below $0^{\circ} \mathrm{C}$ and reach positive daily values only for few short summer months (1-4 months) or weeks. Consistent with this, Convey et al. (2018) reported that on Signy Island, the annual mean of ground temperature is $1.7^{\circ} \mathrm{C}$ whereas annual maximum and minimum is 18.4 and $-8.7^{\circ} \mathrm{C}$, respectively. As for air temperature, the mean monthly temperature reach low positive values during summer, with annual mean of $-3.9^{\circ} \mathrm{C}$ and annual maximum and minimum of 8.6 and $-30.1^{\circ} \mathrm{C}$, respectively. Biological activity will be minimal or undetectable during sub-zero habitual temperatures. Hence, any bioremediation approaches will only be effective during brief polar summer period when, with positive temperatures, unfrozen soils will have accessible water sources (Lee et al., 2018). It is important to note that strain $\mathrm{AQ5}-15$, being psychrotolerant where the strain is viable at temperature range of $5-25^{\circ} \mathrm{C}$ (Subramaniam et al., 2019) and even at optimum temperature $>15^{\circ} \mathrm{C}$, is able to grow and function well at suboptimal positive temperatures, hence this strain still has the potential to grow and degrade phenol sub-optimally in Antarctic soils. The RSM model was validated using the values predicted for each parameter as shown in Table 7. The result showed no significant difference between the percentage of phenol degradation given by both predicted $(95.33 \%)$ and experimental approaches $(96.42 \%)$.

Fig. 3 shows degradation of different concentrations of phenol by strain AQ5-15 under optimised conditions obtained from CCD. The strain has the ability to degrade phenol up to $1.5 \mathrm{~g}$ $\mathrm{I}^{-1}$ within $24 \mathrm{hr}$. On increacsing the phenol concentration to $1.7 \mathrm{~g} \mathrm{l}$ 1 , the strain started to lose its degradation ability. Studies on cold tolerant bacteria isolated from alpine soils of Binaloud Mountains have shown that Pseudomonas sp. strain ATR208 can completely degrade phenol up to $0.6 \mathrm{~g} \mathrm{l}^{-1}$ at higher time (Sepehr et al., 2019). On the basis of previous studies, Antarctic microorganisms are reported to degrade phenol up to $0.5 \mathrm{~g} \mathrm{l}^{-1}$ at temperature as low as $10^{\circ} \mathrm{C}$ (Gerginova et al., 2013; Lee et al., 2018). Phenol is a major constituent in fuel oil, pharmaceutical and personal care products (Kim et al., 2018; Harley et al., 2019) and can be released into the Antarctic environment via many channels, particularly during marine accidents and the disposal of 'grey water' wastes from research stations (Emnet et al., 2015; Vázquez et al., 2017; Martorell et al., 2019). Singh et al. (2013) 
reported that petroleum wastewater containing $140-480 \mathrm{mg} \mathrm{I}^{-1}$ of oil included phenol at concentrations ranging from $1.2-3.71 \mathrm{mg} \mathrm{l}^{-1}$. Antarctica has also experienced multiple marine accidents with the release of large quantities of oil. For instance, a major fuel oil spill occurred in 1989 when the Argentine vessel Bahia Paraiso, that was en route to resupply an Argentinian research station, ran aground and sank near Palmer Station, Anvers Island, Antarctic Peninsula, releasing over 150000 gallons of diesel (Kennicutt et al., 1991). Recently, a similar event took place in the Galápagos Islands in December 2019, where a barge carrying 600 gallons of diesel oil sank off the dock (Oxford Analytica, 2019). Having highly persistent and anti-microbial properties, phenol can accumulate in the environment to high concentration (Krastanov et al., 2013; Sachan et al., 2019). Thus, this is the first report of an Antarctic bacterium Arthrobacter sp. strain AQ5-15 with higher tolerance and ability to degrade high concentration of phenol at $15^{\circ} \mathrm{C}$.

In conclusion, statistical optimisation by $\mathrm{RSM}$ revealed that the combination of $0.5 \mathrm{gl}^{-1}\left(\mathrm{NH}_{4}\right)_{2} \mathrm{SO}_{4}, 0.13 \mathrm{gl}^{-1} \mathrm{NaCl}, \mathrm{pH} 7.25$, and temperature of $15^{\circ} \mathrm{C}$ resulted in maximum phenol degradation by the native Antarctic soil bacterium, Arthrobacter sp. strain AQ515. The strain could tolerate and degrade an initial concentration of up to $1.5 \mathrm{~g} \mathrm{l}^{-1}$ of phenol under optimised conditions. According to this study, the statistical approach could be a valuable alternative to the conventional one-factor-at-time (OFAT) method for the optimisation of phenol degradation in wastewater treatment.

\section{Acknowledgments}

This work was supported by Matching Grant PUTRA (UPM-YPASM 9300430), YPASM Berth Support, PUTRA-IPS (9631800), PUTRA-Berimpak (9660000). We also thank Universiti Putra Malaysia for providing a GRF scholarship to Kavilasni Subramaniam. P. Convey is supported by NERC core funding to the BAS 'Biodiversity, Evolution and Adaptation' Team.

\section{References}

Ahmad, S.A., G. Asokan, N.A. Yasid, N.M. Nawawi, K. Subramaniam, N.N. Zakaria and M.Y.A. Shukor: Effect of heavy metals on biodegradation of phenol by Antarctic bacterium, Arthrobacter bambusae strain AQ5-003. Malays. J. Biochem. Mol. Biol., 21, 4751 (2018).

Ahmad, S.A., N.A. Shamaan, M.A. Syed, F.A. Dahalan, K. Abdul Khalil, N.A. Rahman and M.Y. Shukor: Phenol degradation by Acinetobacter sp. in the presence of heavy metals. J. Natl. Sci. Found. Sri., 45, 247-253(2017).

Alben, K.T.: Design, analyze and optimize with Design-Expert. Anal. Chem., 74, 222-223 (2002).

Anderson, M.J. and P.J. Whitcomb: RSM simplified: Optimizing processes using response surface methods for design of experiments, Productivity Press, New York (2004).

Arrhenius, S.: Quantitative relationship between the rate a reaction proceed and its temperature. J. Phys. Chem., 4, 226-248 (1889).

Bargagli, R.: Environmental contamination in Antarctic ecosystems. Sci. Total Environ., 400, 212-226(2008).

Caetano, M., C. Valderrama, A. Farran and J.L. Cortina: Phenol removal from aqueous solution by adsorption and ion exchange mechanisms onto polymeric resins. J. Colloid. Interf. Sci., 338, 402-409 (2009).

Chen, Y., H. He, H. Liu, H. Li, G. Zeng, X. Xia and C. Yang: Effect of salinity on removal performance and activated sludge characteristics in sequencing batch reactors. Bioresour. Technol., 249, 890-899 (2018).

Convey, P., S.J. Coulson, M.R. Worland and A. Sjöblom: The importance of understanding annual and shorter-term temperature patterns and variation in the surface levels of polar soils for terrestrial biota. PolarBiol., 41, 1587-1605 (2018).

Das, N. and P. Chandran: Microbial degradation of petroleum hydrocarbon contaminants: an overview. Biotechnol. Res. Int., 2011, 1-13 (2011).

Emnet, P., S. Gaw, G. Northcott, B. Storey and L. Graham: Personal care products and steroid hormones in the Antarctic coastal environment associated with two Antarctic research stations, McMurdo Station and Scott Base. Environ. Res., 136, 331-342 (2015)

Gerginova, M., J. Manasiev, H. Yemendzhiev, A. Terziyska, N. Peneva and Z. Alexieva: Biodegradation of phenol by Antarctic strains of Aspergillus fumigatus. Z. Naturforsch. C.J. Biosci., 68, 384-393 (2013).

Gran-Scheuch, A., E. Fuentes, D.M. Bravo, J.C. Jiménez and J.M. Pérez-Donoso: Isolation and characterization of phenanthrene degrading bacteria from diesel fuel-contaminated Antarctic soils. Front. Microbiol., 8, 1-12 (2017).

Harley, K.G., K.P. Berger, K. Kogut, K. Parra, R.H. Lustig, L.C. Greenspan, A.M. Calafat, X. Ye and B. Eskenazi: Association of phthalates, parabens and phenols found in personal care products with pubertal timing in girls and boys. Hum. Reprod., 34, 109-117 (2019).

Ibrahim, S., M.Y. Shukor, K.A. Khalil, M.I.E. Halmi, M.A. Syed and S.A. Ahmad: Application of response surface methodology for optimising caffeine-degrading parameters by Leifsonia sp. strain SIU. J. Environ. Biol., 36, 1215-1221 (2015).

Ibrahim, S., K.N.M. Zahri, P. Convey, K. Abdul Khalil, C. Gomez-Fuentes, A. Zulkarnain, S.A. Alias, G. González-Rocha and S.A. Ahmad: Optimisation of biodegradation conditions for waste canola oil by cold-adapted Rhodococcus sp. AQ5-07 from Antarctica. Electron. J. Biotechnol., 48 (2020). doi:10.1016/j.ejbt.2020.07.005

Jara-Carrasco, S., R. Barra, W. Espejo, J.E. Celis, D. González-Acuña, G. Chiang and J. Sánchez-Hernández: Persistent organic pollutants and porphyrin levels in excreta of penguin colonies from the Antarctic Peninsula area. Polar Rec., 53, 79-87(2017).

Karamba, K.I., S.A. Ahmad, A. Zulkharnain, M.A. Syed, K.A. Khalil, N.A. Shamaan, F.A. Dahalan and M.Y. Shukor: Optimisation of biodegradation conditions for cyanide removal by Serratia marcescens strain $\mathrm{AQ} 07$ using one-factor-at-a-time technique and response surface methodology. Rend. Lincei., 27, 533-545(2016).

Kennicutt, M.C., S.T. Sweet, W.R. Fraser, W.L. Stockton and M. Culver: Grounding of the Bahia Paraiso at Arthur Harbor, Antarctica. 1. Distribution and fate of oil spill related hydrocarbons. Environ. Sci. Technol., 25, 509-518(1991).

Kim, H., N.R. Vinueza, S.S. Kelley and S. Park: Correlation between solubility parameters and recovery of phenolic compounds from fast pyrolysis bio-oil by diesel extraction. Carbon Resour. Convers., 1, 238-244(2018).

Krastanov, A., Z. Alexieva and H. Yemendzhiev: Microbial degradation of phenol and phenolic derivatives. Eng. Life Sci., 13, 76-87(2013).

Kulkarni, P. R., D.C. King, T.E. McHugh, D.T. Adamson and C.J. Newell: Impact of temperature on groundwater source attenuation rates at hydrocarbon sites. Ground Water Monit. R., 37, 82-93 (2017). 
Lee, G.L.Y., S.A. Ahmad, N.A. Yasid, A. Zulkharnain, P. Convey, W.L. Wan Johari and M.Y. Shukor: Biodegradation of phenol by coldadapted bacteria from Antarctic soils. Polar Biol., 41, 553-562 (2018).

Lee, S.Y., S.A. Ahmad, S.R. Mustapha and J. Ong-Abdullah: Ability of Ipomoea aquatica Forssk. to remediate phenol in water and effects of phenol on the plant's growth. Pertanika J. Sci. Technol., 25, 441$452(2017)$.

Li, Y., J. Li, C. Wang and P. Wang: Growth kinetics and phenol biodegradation of psychrotrophic Pseudomonas putida LY1. Bioresour. Technol., 101, 6740-6744 (2010).

Martorell, M.M., L.A.M. Ruberto, L.I.F. de Castellanos and W.P. Mac Cormack: Bioremediation abilities of Antarctic fungi. In: Fungi in Extreme Environments: Ecological Role and Biotechnological Significance (Eds.: S.M. Tiquia-Arashiro and M. Grube) Springer, Switzerland, pp. 517-534 (2019).

Mazuki, T.A.T., M.Y. Shukor and S.A. Ahmad: Bioremediation of phenol in Antarctic: A mini review. Malays. J. Biochem. Mol. Biol., 22, 1-6 (2019).

Mijangos, F., F. Varona and N. Villota: Changes in solution color during phenol oxidation by Fenton reagent. Environ. Sci. Technol., 40, 5538-5543 (2006).

Mohammadi, S., A. Kargari, H. Sanaeepur, K. Abbassian, A. Najafi and E. Mofarrah: Phenol removal from industrial wastewaters: A short review. Desalin. Water Treat., 53, 2215-2234 (2015).

Nawawi, N.M., S.A. Ahmad, M.Y. Shukor, M.A. Syed, K.A. Khalil, N.A. Ab Rahman, F.A. Dahalan and A.L. Ibrahim: Statistical optimisation for improvement of phenol degradation by Rhodococcus sp. NAM 81. J. Environ. Biol., 37, 443-451 (2016).

Oxford Analytica: Galapagos spill to fuel Ecuador government criticism. Emerald Expert Briefings (2019).

Patil, S.S. and H.M. Jena: Statistical optimization of phenol degradation by Bacillus pumilus OS1 using Plackett-Burman design and response surface methodology. Arab J. Sci. Eng., 40, 2141-2151 (2015).

Priyadharshini, S.D. and A.K. Bakthavatsalam: Optimization of phenol degradation by the microalga Chlorella pyrenoidosa using Plackett-Burman design and response surface methodology. Bioresour. Technol., 207, 150-156 (2016).

Roslee, A.F.A., N.N. Zakaria, P. Convey, A. Zulkharnain, G.L.Y. Lee, C. Gomez-Fuentes and S.A. Ahmad: Statistical optimisation of growth conditions and diesel degradation by the Antarctic bacterium, Rhodococcus sp. strain AQ5-07. Extremophiles, 23, 115(2019).

Sachan, P., S. Madan and A. Hussain: Isolation and screening of phenoldegrading bacteria from pulp and paper mill effluent. Appl. Water Sci., 9, 1-6 (2019).

Shah, M.P.: Microbial degradation of phenol by an application of Pseudomonas mendocina. Austin J. Microbiol., 4, 1-4 (2018).

Sanusi, S.N.A., M.I.E., Halmi, S.R.S. Abdullah, H.A. Hassan, F.M. Hamzah and M. Idris: Comparative process optimization of pilotscale total petroleum hydrocarbon (TPH) degradation by Paspalum scrobiculatum L. Hack using response surface methodology (RSM) and artificial neural networks (ANNs). Ecol. Eng., 97, 524-534 (2016).

Sepehr, S., B. Shahnavaz, A. Asoodeh and M. Karrabi: Biodegradation of phenol by cold-tolerant bacteria isolated from alpine soils of Binaloud Mountains in Iran. J. Environ. Sci. Hlth. A, 54, 367-379 (2019).
Singh, A., V. Kumar and J.N. Srivastava: Assessment of bioremediation of oil and phenol contents in refinery wastewater via bacterial consortium. J. Pet. Environ. Biotechnol., 4, 1-4 (2013).

Sivasubramanian, S. and S.K.R. Namasivayam: Phenol degradation studies using microbial consortium isolated from environmental sources. J. Environ. Chem. Eng., 3, 243-252 (2015).

Suárez-García, L., F. Cuervo-López, and A.C. Texier: Biological removal of mixtures of ammonium, phenol, cresol isomers and sulfide in a sequencing batch reactor. Rev. Mex. Ing. Quim., 18, 1189-1202 (2019).

Subramaniam, K., T.A.T. Mazuki, M.Y. Shukor and S.A. Ahmad: Isolation and optimisation of phenol degradation by Antarctic isolate using one factor at time. Malaysia J. Biochem. Mol. Biol., 22, 79-86 (2019).

Téllez-Pérez, S.K., C.D. Silva and A.C. Texier: Simultaneous ammonium and $\mathrm{p}$ - hydroxybenzaldehyde oxidation in a sequencing batch reactor. Rev. Mex. Ing. Quim., 12, 97-104 (2013).

Tengku-Mazuki, T.A., K. Subramaniam, N.N. Zakaria, P. Convey, K. Abdul Khalil, G.L.Y. Lee, A. Zulkharnain, N.A. Shaharuddin and S.A. Ahmad: Optimization of phenol degradation by Antarctic bacterium Rhodococcus sp. Antarct. Sci., doi: 10.1017/ S0954102020000358 (2020).

Vajić, U.-J., J. Grujić-Milanović, J. Živković, K. Šavikin, D. Gođevac, Z. Miloradović, B. Bugarski and N. Mihailović-Stanojević: Optimization of extraction of stinging nettle leaf phenolic compounds using response surface methodology. Ind. Crops Prod., 74, 912-917(2015)

Varjani, S.J. and V.N. Upasani: A new look on factors affecting microbial degradation of petroleum hydrocarbon pollutants. Int. Biodeter. Biodegr., 120, 71-83(2017).

Vázquez, S., P. Monien, R. P. Minetti, J. Jürgens, A. Curtosi, J.V. Primitz, S. Frickenhaus, D. Abele, W. Mac Cormack and E. Helmke: Bacterial communities and chemical parameters in soils and coastal sediments in response to diesel spills at Carlini Station, Antarctica. Sci. Total Environ., 605, 26-37 (2017).

Vera Candioti, L., M.M. De Zan, M.S. Cámara and H.C. Goicoechea: Experimental design and multiple response optimization. Using the desirability function in analytical methods development. Talanta, 124, 123-138 (2014).

Yaacob, N.S., R. Mohamad, S.A. Ahmad, H. Abdullah, A.L. Ibrahim and A.B. Ariff: The influence of different modes of bioreactor operation on the efficiency of phenol degradation by Rhodococcus UKMP. 5M. Rend. Lincei, 27, 749-760 (2016).

Yusuf, I., S.A. Ahmad, L.Y. Phang, M.A. Syed, N.A. Shamaan, K.A. Khalil, F.A. Dahalan and M.Y. Shukor: Keratinase production and biodegradation of polluted secondary chicken feather wastes by a newly isolated multi heavy metal tolerant bacterium-Alcaligenes sp.AQ05-001. J. Environ. Manage., 183, 182-195 (2016).

Zakaria, N.N., S.A. Ahmad, G.L.Y. Lee, N.A. Yasid, M. Manogaran, K. Subramaniam, T.A. Tengku Mazuki, N.M. Nawawi and M.Y. Shukor: Biodegradation of phenol by Antarctic bacterium Rhodococcus baikonurensis strain AQ5-001 in the presence of heavy metals. Malays. J. Biochem. Mol. Biol., 21, 29-36 (2018).

Zhou, J., X. Yu, C. Ding, Z. Wang, Q. Zhou, H. Pao and W. Cai: Optimization of phenol degradation by Candida tropicalis Z-04 using Plackett-Burman design and response surface methodology. Int. J. Environ. Sci., 23, 22-30 (2011). 